\title{
Competency improvement through internship: An evaluation of corporate social responsibility program in vocational school
}

\author{
Mgs. Ahmad Ramadhani, Ety Rahayu \\ Department of Social Welfare, Universitas Indonesia, Indonesia
}

\begin{tabular}{l} 
Article Info \\
\hline Article history: \\
Received Mar 8, 2020 \\
Revised Jun 21, 2020 \\
Accepted Jul 17, 2020 \\
\hline
\end{tabular}

\section{Keywords:}

Competence

Corporate social responsibility

Internship

Vocational education

\begin{abstract}
The high unemployment rate in Indonesia derived from vocational school graduates could be alleviated through internship as a part of Corporate Social Responsibility program that deployed by company together with school to equip its students or graduates with set of competences, therefore they will be competent and able to compete in job market, especially in the era of disruptive technologies. This applied research of evaluation using qualitative approach aimed to evaluate the input and process of the corporate social responsibility program in vocational internship conducted by an oil and gas manufacturing company in Indonesia. The results of this revealed some inputs that were the source of program success and processes that determined the quality of the program. Aspects of input generally met the ideal criteria such as competent program staff, participant characteristic reflecting program objectives, flexible and synchronized curriculum, adequate facility, and available procedure. Aspects of the process complied with regulations and procedures as well. Both aspects resulted the achievement of outcome that exceeded expectation such as competence improvement, cost saving, awards and provide information to be replicated by other institutions.
\end{abstract}

This is an open access article under the $\underline{C C B Y-S A}$ license.

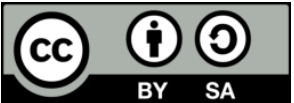

\section{Corresponding Author:}

Mgs. Ahmad Ramadhani,

Department of Social Welfare,

Faculty of Social Sciences \& Politics,

Universitas Indonesia,

Depok, Jawa Barat - 16424, Indonesia.

Email: purnamaperak@gmail.com

\section{INTRODUCTION}

In Indonesia, the highest contributor to open unemployment rate is supplied by vocational school graduates. In August 2018, the dominance of this graduates in that figure was 11.24\% [1]. This was caused by vocational schools supplied skills which not match with the needs of the industry. This mismatch between supply and demand was a result of educational planning which is not oriented to the reality that occurs in society [2]. This issue could get be worsen as due to technological disruptive that it provides many benefits in one hand, but in other hand also gives challenges such as workers displacement by machines or automation [3]. Technology has introduced massive automation over routine and manual tasks, only jobs that require medium-high skills that are not affected by this disruption. As a consequence, low skilled workers will rely on social protection schemes from governments [4]. Unemployment has a significant impact on various aspects, not only on individuals who experience it but also on the family and their social environment, such as poverty [5, 6], increasing crime [7], decreased physical health, income, children's academic [8], affecting psychological $[9,10]$ such as anxiety, depression, violence against his wife and children. 
If we fail to equip them with competencies and do not anticipate future challenges, that Indonesia will encounter a demographic bonus reaching around $70 \%$ active labor force [2], number of unemployment will be hiked, and certainly it will have an impact on people's welfare. Thus, this need to be a major concern for government and other stakeholders namely corporation and schools as participation from others is needed to achieve social development goals [11] and this collaboration was also emphasized by the Sustainable Development Goals (SDGs) in sustainable development [12].

To cope with that issue, the Indonesian government has issued certain policies such as the Presidential Instruction No. 9 of 2016 concerning the revitalization of vocational high schools in a bid to improve quality of human resources in Indonesia, the Regulation of the Minister of Industry no 03/MIND/PER/1/2017 concerning guidelines for guidance and development of competency-based vocational high school that link and match with industry, and the Government Regulation no. 45 of 2019 concerning amendment to the Government Regulation No. 94 of 2010 concerning calculation of taxable income and settlement of income tax in the current year. Those encourage corporation to contribute to the vocational education $[13,14]$, one of which is by deploying better internship.

Current practices of internship so called Prakerind (Practice in Industry) in Indonesia is not really effective, which companies only accept students having activities in industry premise without mentoring them or providing appropriate training so that they could develop their competences. It is quite common that interns be assigned for basic tasks that not related to competences taught at school [15-17]. They are not given the opportunity to learn and possess higher-skilled subjects; despite they will be successor who can later be hired by companies.

Several studies have been conducted related to vocational education, internship or apprenticeship, and its impact such as Hayyat and Hussain in southern Punjab [18], Nordman and Pasquier-Doumer in Africa [19], Sabani in Purbalingga-Indonesia [20], Mahfud in Balikpapan-Indonesia [21], and Hayati in Magelang-Indonesia [22]. In terms of evaluation, Yurikosari evaluated the process of apprenticeship in abroad [23], Marsono, et al. evaluated the effectiveness of internship of university students [24], Afrina, et al. evaluated vocational training in Indonesia [25], Hadisuamardjo evaluated the Corporate Social Responsibility (CSR) effectiveness of three companies in education program in Bogor [26]. However, this research is different and fills the gap of previous researches to evaluate the CSR internship program in the country that develops the competencies of vocational students majoring in engineering in the Oil and Gas manufacturing industry.

There were three reasons researchers conducted this research: the location, the subjects, and the program. Firstly, the program was conducted in Batam - Kepulauan Riau, Indonesia, an industrial city and a special economic zone. Growth rate in Kepulauan Riau from 2010-2017 was classified as high at $3.01 \%$, or the second highest in Indonesia, with an open unemployment rate of $7.16 \%$ in August 2017, the fifth highest under Maluku (9.29\%), Banten (9.28\%), Jawa Barat (8.22\%), and Sulawesi Utara (7.18\%) [27]. Demographically, this city is classified as a strategic area where located in the golden triangle of Sijori (Singapore, Johor, Riau Archipelago) so that enable more trade traffic, community interaction, and information exchange among these regions than other regions. Secondly, the subjects of this research were PT Citra Tubindo Tbk partnering with local vocational school located in surrounding its facility, SMKN 6 Batam who was the only school for the program of Industrial Estate Vocational School (SMK Kawasan Industri) receiving 1 billion rupiahs from the Government from outside Jawa, where economy and politic are most centered in Indonesia, while 9 others coming from Jawa. The predicate of the SMK Kawasan Industri achievement has been pinned since 2016 until 2019 [28] while that partnership has been established since 2014. The school was established in 2010 with limited facilities, only having 2 majors, namely Mechanical Engineering and Computer Networking with a total of 123 students, the majority of them were from lower economic class. It then transformed into well-reputed school as aforementioned. In 2019, SMKN 6 was proposed by the Department of Education Kep. Riau as one of the 18 target schools in Indonesia, who were chosen due to having industrial partners, broadly useful products produced by them, and having learning standard to process the products, to be participants of Vocational School Revitalization Pilot Project together with its industrial partners which aimed to share their experiences in implementing partnership and internship program and working together to revitalize vocational schools. Thirdly, the program had 6 months learning curriculum comprising class room, on job training, and assessment to improve student competence.

These have attracted the attention of researchers to evaluate this program. This study seeks to answer the research question of how is the implementation of the internship program of PT Citra Tubindo Tbk's CSR partnering with SMKN 6 Batam to increase the competence of students and graduates in technological disruptive era. This research is expected to contribute theoretically in term of evaluation of the CSR internship program developing the competencies of vocational students majoring in engineering in the Oil \& Gas manufacturing industry. The result may develop vocational education and training science, social welfare science, and CSR. 


\section{RESEARCH METHOD}

\subsection{Research design}

This study used qualitative research approach with the type of applied research which is evaluation research [29]. In this kind of research, authors used implementation evaluation [30]. This help researcher or evaluator to inform decision makers of the program over what is going on, how it has developed, and how and why programs diverge from the commencing plans and expectation. This kind of evaluation includes attention to input, activities, process, and structures. In analysing the data, researcher combined or referred to model that Pietrzak, et al. developed [31] which is inputs, process, and outcome, however in this study researchers only focused on two former aspects respectively. Input evaluation provides documentation of what made up a successful program, while process evaluation measures operations and quality so that it can identify areas of program change or improvement.

In the input evaluations, variables of interest can be categorized into three classifications which are client, staff, and program factors. Activity refers to actions taken to transform inputs to become specific outputs, while process evaluation refers to assessment of the internal dynamics of the implementing organization, policy, service delivery, management practices, and the linkages among these [32]. In the process or activities, data must be assessed in relevant criteria such as best practice standards, policies, goals, and client satisfaction [31].

\subsection{Data collection method}

To collect relevant data, researchers used literature study [33], observation [34] and semi structured interview methods [34]. Literatures were focused on evaluation pf CSR program, competence, vocational and education. Observation was conducted in company and school premise either related to the program implementation or data collection process. Query list was not absolutely asked in order or rigidly, yet flexibly to get deep data in casual conversation.

\subsection{Sampling method}

The informants were selected by purposive sampling which determined by particular criteria [29]. Six program executors/company staffs, three teachers, and 10 participants/alumni the program have been interviewed. Criteria for staff were they who have been involved in the managing program minimum for one year and able to explain the program. Criteria for interns were participants who have completed six months internship/apprenticeship, got high score in the assessment, and been hired by the company.

\subsection{Study group}

The scope of the study was focused on the CSR program of internship deployed by PT Citra Tubindo Tbk partnering with SMKN 6 Batam since 2014 to 2018 which was not only about internship, yet comprising other activities as shown in Figure 1 that refer to interview in 2019. In the beginning, program staffs analyze manpower needs that can be fulfilled by graduates of the program then prepare learning structure of six months internship which synchronized to the needs and budget. After that they will inform school staffs to screen potential students of $4^{\text {th }}$ semester. School together with company then conduct recruitment process. Those who have been selected will be separated in one class having special curriculum that has been synchronized with company needs. Company staffs will teach them in the school for certain schedule. When they are at $5^{\text {th }}$ semester, they will be having internship at company place.

The internship program was more structured and systematic than other common internships. Both parties worked together to synchronize the curriculum and to deploy the internship for 6 months for last semester students. Company assigned dedicated trainers, mentors, and companions mentoring those interns; provided classrooms, machines, and tools; prepared learning structure and schedule to be followed by interns and trainers.

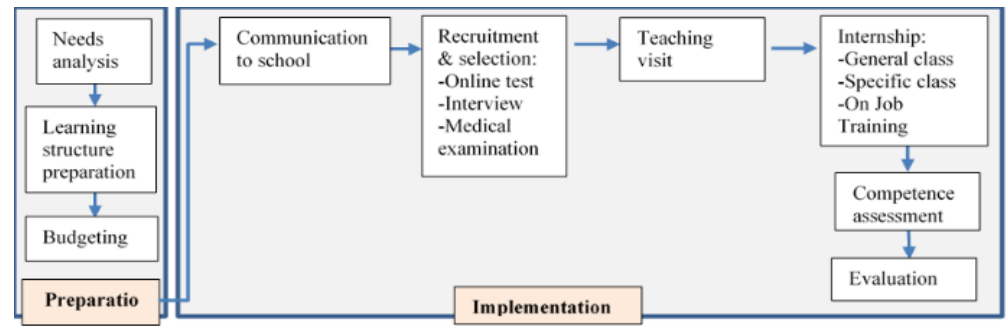

Figure 1. Flow process of internship program of CSR PT Citra Tubindo Tbk 


\subsection{Data analysis}

Researchers refer to Neuman [29] in analyzing qualitative data such as linking certain data to concepts, generalizing, identifying themes, while for evaluation criteria of input and process refer to Pietrzak, et al [31]. The criteria of input refer to objective and program goals, community needs assessment, and best practice standard. The criteria for evaluating the process refer to the best practice standard, policies and procedures, process objectives, and client satisfaction.

\section{RESULTS AND DISCUSSION}

\subsection{Input}

In the input section, the analysis emphasizes whether the beneficiary of CSR of the company which is interns reflecting the objectives of the CSR, whether program management staffs have sufficient qualifications to run the program and achieve goals, and whether other aspects such as curriculum, facilities and procedures become resources for the success of the program.

\subsubsection{Intern}

Ideal requirements of this refer to internal procedures and government regulation such as maximum number of participants, age, education, residency, and passing test. All batches conducted have complied the standard of quantity limit, even far from it which requires less than $30 \%$ of employee population. However, this does not mean that it is necessary to rise the number as need to consider the effectivity of the training, class capacity, and number of machines. The participants have been selected quite rigorously with various selection methods namely screening from school, online tests, interview, and health check. The practice has been revamped from year to year to ensure that selected candidates are the right one to join such as improving interview form, involving teachers in screening, conducting interviewers meeting to determine who will pass.

Participants have generally met the characteristics criteria to achieve the objective of the program which is to improve local community competencies and to fulfil manpower needs. Most of them came from low economy class living in the surrounding industrial estate. Hiring them may elevate the company image and eliminate conflict potential. They, after graduation, can be hired to work and adjust to company's work hours that might not be done by those who go to tertiary institutions who usually come from the upper middle class. As for age, there were $21 \%$ under the age of 18 out of all participants since 2014 to 2018 , though it complies to internship regulation yet not to manpower regulation, thus this resulted in a longer waiting period for them to be able to work, or in other words reducing the success rate of employment of graduates of the program.

\subsubsection{Program staff}

The ideal criteria of this is that there are competent program staffs which is Human Resources (HR) managing the program, trainer, mentor, and companion teaching participants. There were 71 people were involved in teaching general subjects such as quality and safety and technical subjects namely machining, quality inspection, heat treatment, yard operation, and maintenance. They were appointed considering education background, certification, and work experiences. However, not all of them had andragogy or teaching skills thus the way of delivering the material was apprehended less impressed. It was noticed by the the staff then conducted training of trainer to occupy them with appropriate skills. In addition, there were some issues in managing this project such as limited man power, coordination, and turn over which affected the ideal work rhytm.

\subsubsection{Curriculum}

The ideal criteria of this are that to have curriculum, an important reference for learners to achieve target competencies and trainers to teach and stimulate participants to improve competencies, which distinguishes prakerind and this internship program. Since the initial batch, PT Citra Tubindo Tbk has prepared a curriculum called learning structure in the form of information on learning objectives, activities, duration, and whose responsibility. It comprises $30 \%$ of class room teaching interns on quality, safety, general products and processes, and $70 \%$ of on job training or practical process. This figure actually lower than standard which is not exceed than $25 \%$ of class room. This document was also reviewed every batch before starting the internship and the quality was improved from year to year.

The material taught so far is still relevant to the needs and technological development of similar industries. The development of product technology and in the processing of the product itself has not significantly developed compared to other industries. Although in this curriculum they were taught knowledge and skills to operate machines and to inspect product quality, they were not exposed to the 
cutting-edge of technological machines available there. Thus, it would be better to examine the relevance of competencies and to expose them to current techonologies for future needs.

\subsubsection{Infrastructure}

PT Citra Tubindo Tbk has invested quite a lot of facilities for this CSR program. There are some classes need improving to ameliorate conduciveness in the learning process. Although it has not yet had dedicated machines for this purpose, the participants benefited from learning directly at the production line so that they were introduced to the real conditions of working and interacting with the professional environment, which is the main feature of internship/ apprenticeship allowing the effectivity of learning [35]. Interns provided positive feedback in practicing with those machines and in the area of production so that they can learn and practice as they can't do that in the school where machines are not available properly.

The facilities and infrastructure provided are also quite adequate in terms of technology, although as mentioned that not all of them were exposed to high-tech machines. The introduction and habituation of this technology becomes important to deal with the rapid technological development. The provision of smart TVs, tablets, online learning documentation systems and quizzes can stimulate participants to adapt to technology. Moreover, the log book also supports the learning process in terms of reviewing the learning process and can being a reference to recall what has been learned.

\subsubsection{Procedure}

Ideally, staff has a procedure, an important document to standardize the processes that have been carried out and become a reference for implementing the process to be able to repeat the activities to achieve the targets. They have written procedure regarding this as well as some related procedures for the recruitment process of interns and program alumni, however, though it is stated in that document that certain parties need to know the contents of the procedure, it was not disseminated thus they do not know. A summary of all aspects of the input can be seen in Table 1. Most of the actual input met ideal criteria, however some elements did not thus could affect the achievement of program success such as age of participants younger than manpower regulation in the end of the program, number of staffs to manage a lot of workload, longer class room learning period, training rooms need to be repaired, and inconveyed procedure.

Table 1. Input evaluation

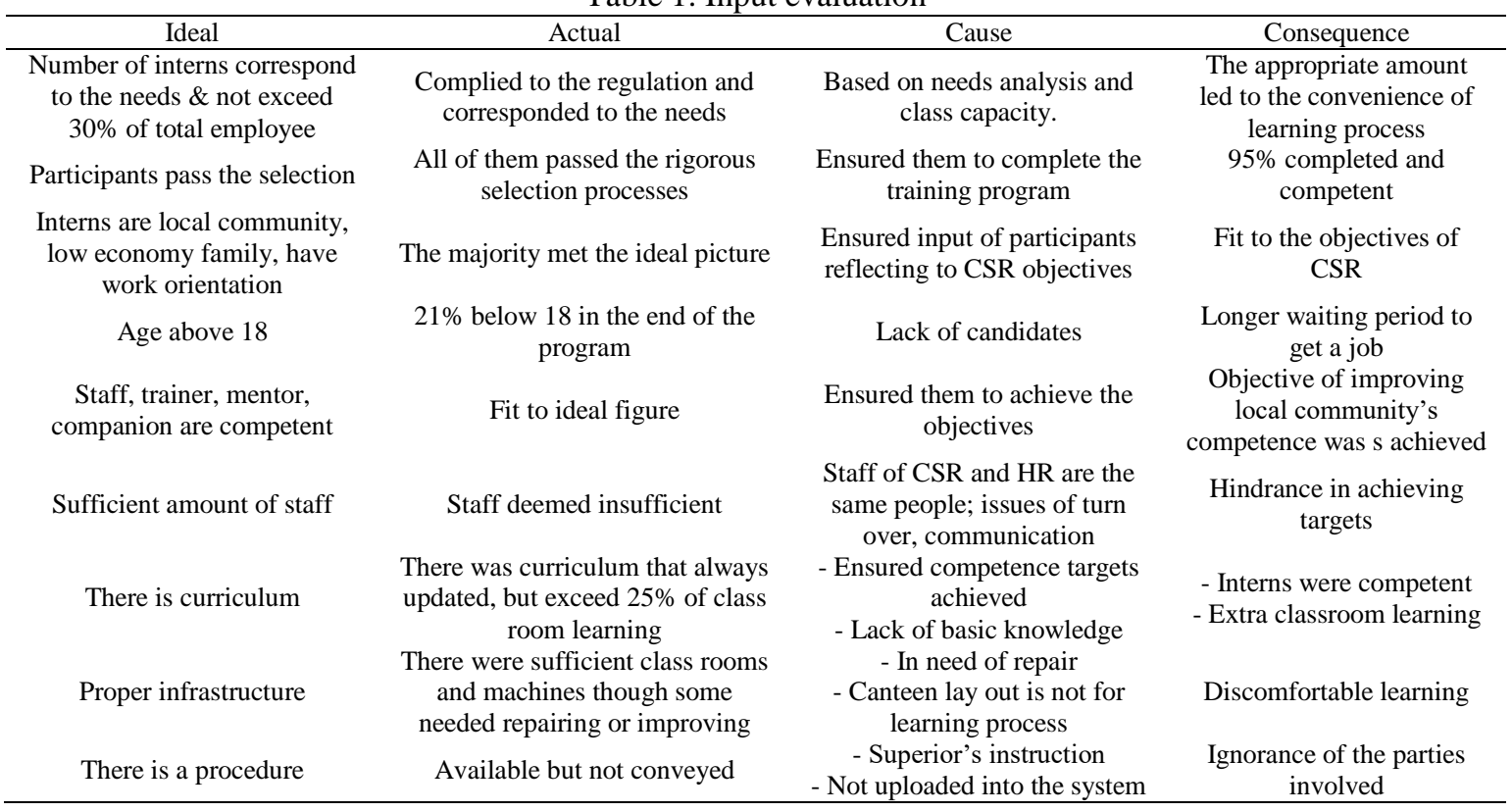

\subsection{Process}

\subsubsection{Need analysis}

Needs analysis is needed to determine how many future workforce needs can be supplied from alumni of this program. Accurate analysis will generate precise quota intern, practical positions, and competencies to be taught. If this is not done properly, it will have an impact on the incompatibility of the competencies of alumni who will be recruited so that it requires additional time to obtain 
competencies that match with the needs. However, this does not mean that it is completely useless, because the competencies taught can also be beneficial for them to get jobs out there, either in similar industry or others.

Overall needs analysis was carried out together between company and school, but needs of each batch had been only analyzed by company and then were informed to the school. The absence of wellorganized and traceable documentation can impede program evaluation and replication. Existing documentation was partial and randomly stored at various online application and server locations. In addition, not all staff know this analysis or the need.

\subsubsection{Preparation of learning structure dan action plan}

This stage was not only carried out by HR staffs in the section of organization and competence, but also involved others from relevant departments that can produce productive cooperation as each department is considered to have a role in the program. The curriculum was always reviewed and revised according to the needs in production. Aligning it to national standards so called SKKNI (Indonesia National Working Competence Standard), although still in process, is an appropriate step to take to recognize competencies being taught so that participants can compete more in the job market. The action plan prepared was an internal discussion among staffs, not a detailed plan and time line document which might negatively influence in achieving targets in the process.

\subsubsection{Budgeting}

As a matter of fact, strategic budget preparation had been done a few months before the initial stage of the whole process, but the detailed budget allocation was made after two previous processes above. Increased additional benefits from the previous batches that have been given to the participants such as learning packages, uniforms, and appreciation to mentors and buddy gave a positive impression for them. This step was documented well, but the overall documentation of total expenditure was less consistent between one and another. This inconsistency of calculation methods could cause problems later on, for example audits.

\subsubsection{Communication to school}

Communication and cooperation were semi-productive as it was still short-term interests and did not create a sense of belonging. Although company tried to offer the principle of mutualism, neither everything worked smoothly nor its goals were achieved. Some teachers perceived not being involved or got benefit from this program. Although the information of needs and the program was conveyed to the school staffs, but the process of communication and cooperation between the two parties was less effective. They argued that due to the lack of teachers and the over workload. Manpower shortages or over workloads were actually complained and occured on both sides. The lack of teachers, financial problems, and teacher attitudes were obstacles to effective cooperation.

The pattern of cooperation undertaken by company was directive which means it informed the needs and directed the plans and strategies that need to be carried out by its partners. School was then passive in receiving informations and instructions. In addition, different communication style that implemented by company was practical while by school was bureaucratic also triggered this problem.

\subsubsection{Teaching visit}

Ideally this process that conducted before internship does not only transfer knowledge to students who will participate in the internship but also to the teachers so that they have more knowledge and can teach other students not being involved. More over, it is expected to reduce the general class schedule (quality, safety, products) in the internship so they can learn much in technical class. In fact, these two ideal conditions were not achieved due to quantity and attitude of teachers. They were expected to be involved in the classroom with students, but they did other tasks. Although the psychological response of the reluctance to learn with students in one class can be understood, the teacher can attend the class by camouflage as an observer or supervisor of ongoing activities.

Supposing that teachers have lack industrial knowledge, this definitely would help them improve it. Therefore, the absence of the knowledge transfer has resulted not only in lack of teachers' knowledge but also dependencies on company to always teach students in subsequent years.

\subsubsection{Internship}

Ideal criteria on this are recruitment process is carried out effectively referring procedures, there is agreement referring regulation, class room and on job training are performed. The selection and recruitment of candidates will determine the quality of participants in following the entire learning process. Having low 
quality of candidates would have an impact on the rate of participants completing the program, low participation, and incompetence. The highest figure of this occurred in 2014, 30.7\% participants of this school left the program. Through the improvement of recruitment practices, this number has declined dramatically in the following years, with only one participant in 2017 and zero in 2016 and 2018. Though company and school had MoU concerning the program, statement letter of participating internship shall be signed by interns and their parents which is is very important to protect the rights and obligations of each party carried out and obeyed. Interns have signed it that prepared by school staff, but company staff didn't keep the copy.

During on job training, participants were flexibly assigned to various processes due to industry needs. Participants are introduced to a variety of work processes so that they can master a number of skills that can be useful for them in the future. On the other hand, this can reduce the expected duration of mastery of the main competencies referring learning structure. However, in the end of the program all participants were all competent.

There were senior companions less willing to accompany and to mentor participants. This issue can be understood as a psychological response due to feelings will be replaced by those who pass the program. The company productive age policy stipulated that employee whose age older than particular productive age of the position, though it is below the normal retirement age, can be terminated earlier. This influenced in participants getting knowledge from senior operators whose abundance hands-on experience operating machines and checking quality of products. However, this can also be deemed as a part of learning process that the interaction of participants with the work environment has an effective impact rather than just the learning process at work [36].

As the majority of the workers is men (88\%), It is considered common that some workers conversed or made a sexual verbal joke among them. Although physical harassment did not occur to women workers or interns, sometimes they did not feel comfort hearing that conversation. However, company has policy and reporting system that employee can report any violation or harassment to related parties in the company.

\subsubsection{Competence assessment}

According to National Professional Certification Agency (BNSP) regulation no 4/BNSP/VII/2014, competency assessment can be done through a variety of ways namely written method, oral examination, practical test, and observation, however presentation which previously used in the program was not necessarily effective due to unfamiliar for vocational learning activities emphasizing practice than theory, school facilities especially inadequate computers, and the economic conditions of families. As a result, they did not deliver their understanding well so that it can be categorized as incompetent. Practical tests and observations are more appropriate to be carried out in the program.

\subsubsection{Evaluation}

Monitoring and evaluation of the processes carried out even though in simple and less systematic way by the program management staff has an important role to ensure the achievement of program objectives and to improve the quality. Monitoring participants doing on job training in the production area, evaluating learning activities every week, applying log book, evaluating situational problems, and distributing evaluation forms to participants at the end of the program have contributed to improve the quality of the program. Various improvements have been made from year to year. A summary of processes is shown in Table 2. Most of the actual processes met ideal criteria referring to procedure, regulation, and process objectives. However, there were some problems or some processes did not meet the ideal criteria thus affected the program delivery and quality. 
Table 2. Process evaluation

\begin{tabular}{|c|c|c|c|}
\hline Ideal & Actual & Cause & Consequence \\
\hline $\begin{array}{c}\text { There is accurate need } \\
\text { analysis }\end{array}$ & Imprecise analysis & $\begin{array}{l}\text { Imprecise forecast, uncertain } \\
\text { sales orders }\end{array}$ & $\begin{array}{c}\text { Mismatch of taught competence } \\
\text { and needed }\end{array}$ \\
\hline $\begin{array}{l}\text { Curriculum is always } \\
\text { updated }\end{array}$ & $\begin{array}{l}\text { It was always reviewed and updated } \\
\text { by all parties }\end{array}$ & $\begin{array}{l}\text { Synchronized to production } \\
\text { needs }\end{array}$ & $\begin{array}{l}\text { Competence output according } \\
\text { to the needs and productive } \\
\text { coordination among parties }\end{array}$ \\
\hline $\begin{array}{c}\text { There is accurate } \\
\text { budgeting }\end{array}$ & $\begin{array}{l}\text { Budgeting was carried out well but } \\
\text { without proper documentation and } \\
\text { expenses record }\end{array}$ & $\begin{array}{l}\text { Different calculation method } \\
\text { and no consensus }\end{array}$ & Potential risk of audit finding \\
\hline $\begin{array}{l}\text { Effective } \\
\text { communication and } \\
\text { coordination }\end{array}$ & Ineffective & $\begin{array}{l}\text { Lack of resources/ man power, } \\
\text { work load, attitude, different } \\
\text { communication style }\end{array}$ & Ineffective and passive \\
\hline $\begin{array}{l}\text { Teaching visit carried } \\
\text { out by involving } \\
\text { teachers }\end{array}$ & Teachers did not participate & Lack of teachers & $\begin{array}{l}\text { Lack of knowledge transfer, } \\
\text { dependencies on the company } \\
\text { to repeat the process }\end{array}$ \\
\hline Effective recruitment & Quality was improved & Evaluation & $\begin{array}{l}\text { Declined number of participants } \\
\text { leaving the program }\end{array}$ \\
\hline Valid aggreeement & $\begin{array}{l}\text { MoU between company and school. } \\
\text { Interns signed statement letter but } \\
\text { company did not keep the copy }\end{array}$ & Not following procedure & $\begin{array}{l}\text { Potential risk in case of work } \\
\text { accident }\end{array}$ \\
\hline $\begin{array}{l}\text { Effective class room } \\
\text { and on job training }\end{array}$ & $\begin{array}{l}\text {-class room and on job training were } \\
\text { performed } \\
\text {-on job training was not according to } \\
\text { the plan, uncooperative companions, } \\
\text { harrashment }\end{array}$ & $\begin{array}{c}\text {-Adjustment to production } \\
\text { needs } \\
\text {-Psychological response } \\
\text { concerning to be laid off and } \\
\text { replaced } \\
\text {-majority of workers is men }\end{array}$ & $\begin{array}{l}\text {-Reduction in on job training of } \\
\text { target competence } \\
\text {-Lack of learning process with } \\
\text { companions } \\
\text {-verbal harrasment }\end{array}$ \\
\hline $\begin{array}{l}\text { Effective competence } \\
\text { assessment }\end{array}$ & $\begin{array}{l}\text { Presentation deemed less effective or } \\
\text { inappropriate method }\end{array}$ & $\begin{array}{l}\text { School facility, practical } \\
\text { learning, economy background }\end{array}$ & $\begin{array}{l}\text { Ineffective method to assess } \\
\text { competences }\end{array}$ \\
\hline There is an evaluation & $\begin{array}{l}\text { Monitoring and evaluation on certain } \\
\text { issues or the whole program were } \\
\text { performed though not systematic }\end{array}$ & $\begin{array}{l}\text { Analysis and investigation to } \\
\text { improve the program }\end{array}$ & $\begin{array}{c}\text { There was improvent from year } \\
\text { to year }\end{array}$ \\
\hline
\end{tabular}

\section{CONCLUSION}

Social problems such as unemployment can be tackled together between industries and schools through an internship CSR program to improve student competency to be ready to compete in the job market. This evaluation research emphasized the program evaluation on the aspects of input and process in order to provide an understanding of the success of the program, analysis of problems in implementation, and information for improvement or replication.

Based on the description of the data findings and analysis aforementioned, research finding revealed that the input aspects bring together for delivery of internship program to function successfully in improving student competencies are competent program staff, trainer, and companion managing the program; participant characteristic that reflect the CSR goal; the flexible and synchronized curriculum with various needs; adequate facility; and available and conveyed procedure. Overall, the program has possessed some ideal input criteria. This study also provided evidence of process quality assessment and problem isolated that suggested for improvement and information for replication of effective similar internship program in this technological disruptive era. Despite the processes have generally met objectives and standards stipulated in regulation and procedure, area for improvement are accurate analysis, communication among stakeholders, teacher involvement in the program, and proper assessment method.

The following input recommendations are proposed on the basis of the findings of this study: to recruit students who will be 18 years old in the end of the program or school graduation considering minimum working age; to manage administration more neatly and to disseminate procedures to related stakeholders, though current curriculum and competences are still relevant to the need and technology of Oil and Gas manufacturing companies, it would be better to analyze, review, and synchronize it in preparing for future needs and technology; to review tasks distribution of program staffs; to improve facilities and infrastructures and to adjust them in accordance with technologies development. In terms of process aspects, researchers recommend to maintain appreciation or incentive program for mentors and companions and collaborative work in preparing curriculum; to improve communication and coordination between company and school staffs; to keep records of administration more neatly; and to use observation and practical test methods for competence assessment as more suitable to vocational education. 


\section{REFERENCES}

[1] Badan Pusat Statistik, "Indonesian labor conditions in August 2018" 2018.

[2] Kemendikbud, A flash of two years of vocational high school revitalization in September 2016-2018. Jakarta: Direktorat Pembinaan SMK, 2018.

[3] M. Xu, J. M. David, and S. H. Kim, "The fourth industrial revolution: Opportunities and challenges," Int. J. Financ. Res., vol. 9, no. 2, pp. 90-95, 2018

[4] World Economic Forum, "Eight futures of work scenarios and their implications." World Economic Forum, 2018, [Online]. Available: www3.weforum.org/docs/WEF_FOW_Eight_Futures.pdf

[5] M. Hlinkova, "The long-term unemployment and poverty as an interdisciplinary problem," Eur. Sci. J. ESJ, vol. 9, no. 19, pp. 363-366, Jul 2013.

[6] A. Šileika and J. Bekeryte, "The theoretical issues of unemployment, poverty and crime coherence in the terms of sustainable development," J. Secur. Sustain. Issues, vol. 2, no. 3, pp. 59-70, 2013.

[7] G. Hannie Te and M. Frans, "Societal consequences of youth unemployment," in Youth unemployment and society, P. Anne and M. Jeylan, Eds. New York: Cambridge University Press, 1994.

[8] A. Nichols, J. Mitchell, and S. Lindner, "Consequences of long-term unemployment," The Urban Institute, Jul 2013, [Online]. Available: https://www.urban.org/sites/default/files/publication/23921/412887-Consequencesof-Long-Term-Unemployment.PDF

[9] D. Fryer, "Psychological or material deprivation: Why does unemployment have mental health consequences?" in Understanding unemployment: New perspective on active labour market policies, E. Mclaughlin, Ed. New York: Routledge, 1992.

[10] D. Fryer, "Insecurity, the restructuring of unemployment and mental health," in Unemployment and health: International and interdisciplinary perspectives, T. Kieselbach, A. H. Winefield, C. Boyd, and S. Anderson, Eds. Bowen Hills, QLD: Australian Academic Press, 2006.

[11] J. Midgley, Social Development: Theory and Practice. 55 City Road, London: SAGE Publications Ltd, 2014.

[12] GRI, UN Global Compact, and WBCSD, "SDG Compass: The guide for business action on the SDGs." GRI, UN Global Compact, and the WBCSD, 2015, [Online]. Available: https://sdgcompass.org/wpcontent/uploads/2015/12/019104_SDG_Compass_Guide_2015.pdf

[13] S. Hadam, N. Rahayu, and A. N. Ariyadi, Strategy of vocational school revitalization implementation (10 steps of vocational school revitalization). Jakarta: Kementerian Pendidikan Indonesia, 2017.

[14] Kementerian Perindustrian, "Ministry of industry issued industrial-based vocational education regulation," 2017. [Online]. Available: https://www.kemenperin.go.id/artikel/17009/Kemenperin-Terbitkan-Aturan-PendidikanKejuruan-Berbasis-Industri

[15] D. Ariyanti, "Evaluation of internship in SMK negeri 1 Sayung," M.S. Thesis, Universitas Kristen Satya Wacana, Salatiga, 2015.

[16] A. Kurnia, "Evaluation of internsip program on the competency of sharia banking at SMKN 20 Jakarta," B.S. Thesis, UIN Syarif Hidayatullah, Jakarta, 2019.

[17] D. Anggraeni, "Management of internship program (prakerin) on accounting competency in SMK negeri 2 Pekalongan,” B.S. Thesis, Universitas Negeri Semarang, Semarang, 2017.

[18] A. Hayyat and S. Hussain Chughtai, "The impact of vocational training on poverty alleviation through moderation role of foreign funds; Evidence from southern punjab," Manag. Stud. Econ. Syst., vol. 2, no. 2, pp. 157-171, 2015.

[19] C. J. Nordman and L. Pasquier-Doumer, "Vocational education, on-the-job training, and labour market integration of young workers in urban West Africa," PROSPECTS, vol. 44, no. 3, pp. 445-462, Sep 2014.

[20] I. A. Sabani, Sulistyowati, and M. Adnan, "Analysis of poverty alleviation policies through boarding school education in SMK negeri Purbalingga," J. Polit. Gov. Stud., vol. 6, no. 03, Art. no. 03, Jul 2017.

[21] B. Kusuma, Y. Mulyani, and T. Mahfud, "Competency map of the soft skills apprenticeship program in the Balikpapan hospitality industry," in Prosiding Seminar Nasional UNS Vocational Day, Oct 2018.

[22] F. Z. Hayati, "Community empowerment through the vocational village program in the village of Gedungsari subdistrict of North Magelang, Magelang City," B.S. Thesis, UIN Sunan Kalijaga, 2016.

[23] A. Yurikosari, "Review of the overseas apprenticeship implementation in the context of placement (Study of the minister of manpower and transmigration regulation no. 08/2008)," J. Huk. PRIORIS, vol. 5, no. 1, pp. 45-62, 2015.

[24] Marsono, M. Sugandi, Tuwoso, and Purnomo, "Study the impact of internship on improving engineering students' competency," AIP Conf. Proc., vol. 1887, no. 1, p. 020064, Sep 2017.

[25] E. Afrina, et al., Good practices in vocational training in Indonesia: Case study of three training centers of central government, local government, and private sector. Jakarta: Perkumpulan Prakarsa, 2019.

[26] H. Hadisuamardjo, "Effectiveness of CSR program policy implementation in education," J. Adm. Pendidik. UPI, vol. 21, no. 2, pp. 51-67, Oct 2014.

[27] Badan Pusat Statistik, Indonesian statistics 2018. Jakarta: Badan Pusat Statistik, 2018

[28] S. Manalu, "SMK negeri 6 batam entered the industrial estate, through this program teachers and students can do internship," Tribun Batam, Feb 07, 2019. [Online]. Available: https://batam.tribunnews.com/2019/02/07/smknegeri-6-batam-masuk-smk-kawasan-industri-lewat-program-ini-guru-dan-siswa-bisa-magang

[29] W. L. Neuman, Social research methods: Qualitative and quantitative approaches, Seventh. Harlow, Essex: Pearson Education Limited, 2014.

[30] M. Q. Patton, Qualitative research \& evaluation methods, 3rd ed. Thousand Oaks, CA: Sage Publications, 2002.

[31] J. Pietrzak, M. Ramler, T. Renner, L. Ford, and N. Gilbert, Practical program evaluation: Examples from child abuse prevention. California: Sage Publication, Inc, 1990. 
[32] The World Bank Group, Building skills to evaluate development intervention. Netherlands: International Program for Development Training (IPDET), 2004.

[33] M. Alston and W. Bowles, Research for social workers, an introduction to methods, Second edition. Crows Nest: Allen \& Unwin, 2003.

[34] Marvin. C. Alkin, Evaluation essentials: From a to z. New York: The Guilford Press, 2011.

[35] A. Fuller and L. Unwin, "A sense of belonging: The relationship between community and apprenticeship," in Apprenticeship towards a new paradigm of learning, P. Anley and H. Rainbird, Eds. London: Kogan Page Limited, pp. $150-162,1999$.

[36] L. Filliettaz, "Guidance as an interactional accomplishment practice-based learning within Swiss VET system," in Learning through practice: Models, traditions, orientations, and approaches, S. Billet, Ed. New York: Springer, pp. 156-179, 2010. 